Pobrane z czasopisma Wschód Europy http://journals.umcs.pl/we Data: 26/04/2023 13:30:24

D0I:10.17951/we.2020.6.1.173-193 $\quad$ Wschód Europy • Восток Европы • East of Europe vol 6, 1 / 2020

Виктория Черникова

ORCID ID: https://orcid.org/0000-0003-3091-9619

Воронежский государственный университет, Россия

\title{
Политика памяти: региональная интерпретация
}

П роблема формирования идентичности в политическом и научном дискурсе была актуализирована с появлением России как самостоятельного государства. Ещё более активны стали поиски «национальной идеи» в 2000-е годы. Под редакцией С. С. Сулакшина выходит исследование «Национальная идея России» в 6 томах ${ }^{1}$. Однако издание не предложило четкой и емкой формулы «национальной идеи». Поиск основы консолидации нации сохраняется.

Одним из аспектов, основ формирования идентичности, выступает историческая память. «Общая память о прошлом создает ощущения сходства, принадлежности, связанности, необходимые для идентификации себя в качестве члена сообщества» ${ }^{2}$. Формулируя обоснование данного исследования, стоит учитывать, что основным субъектом осуществления политики памяти выступает государство, однако именно на локальном уровне интерпретируется контекст государственной политики памяти, что требует самостоятельного осмысления.

Целью настоящей статьи является анализ политики памяти на региональном уровне, выявление влияния федеральных трендов и собственно региональных интерпретаций исторических нарративов, которые предлагают связную картину исторических событий.

\section{Концептуальные основы политики памяти}

Теорию вопроса, связывающего память и историю, одним из первых начал разрабатывать в 1920-е гг. Морис Хальбвакс. На основании устойчивости этой

Национальная идея России, в 6 т. Москва: Научный эксперт, 2012.

2 И. Глебова, Историческая память и самоидентификация в современной России, [в:] Польша - Россия. Поиски новой идентичности. Сходства и различия, ред. А. Д. Ротфельд, Варшава, 2017, т. 2, с. 123. 
связи он развивал и отстаивал идею социальной природы памяти, рассматривая механизм формирования коллективной памяти ${ }^{3}$.

Прослеживается устойчивая связь исторических событий с процессом формирования идентичности, поскольку «сохранение памяти - важнейшее условие самоопределения индивидов и укрепления единства социальных групп» ${ }^{4}$ Ряд исследователей (например, Я.-В.Мюллер ${ }^{5}$ ) отмечают, что пробуждение интереса к прошлому стало результатом развития информационных технологий, которые визуализируют историю. О. Малинова считает, что «современный „бум памяти” - одно из очевидных следствий третьей волны демократических транзитов» ${ }^{6}$. Пьер Нора очень ёмко описывает этот процесс: «Тоталитарные государства пытались навязать населению некую официальную версию исторического прошлого. Коллективное осознание этого факта способствовало пробуждению интереса к собственной истории после падения тоталитарных режимов» ${ }^{7}$. Неслучайно именно в период смены политического режима в России наблюдается научный и практический интерес к политике памяти.

После распада СССР в России, как и в других постсоветских странах, начался процесс формирования новой общегражданской идентичности. Активный поиск основ её конструирования обусловлен не только «кризисом идентичности», но и демократизацией, которая вызвала новые процессы в обществе. Как подчеркивает Адам Даниэль Ротфельд, анонсируя эссе Эдмунда Внук-Липиньского, «самоидентификация выражает состояние сознания лишь в условиях демократического государства, в котором мысли и поступки граждан не подвергаются контролю со стороны тоталитарного государства, независимо от того, коммунистический это строй, фашистский, национал-социалистический или же другой, подчиненный определенной идеологии, ограничивающей гражданские права и свободы и навязывающей индивидам их идентичность» ${ }^{8}$.

Политика памяти стала объектом исследования отечественных политологов сравнительно недавно, что обусловлено процессами, связанными с поиском и формированием новой российской идентичности. Наиболее интересны рабо-

3 М. Хальбвакс, Коллективная и историческая память, „Неприкосновенный запас”, 2005. № 2-3 (40-41), http: magazines.russ.ru/nz/2005/2/ha2.html, 10.01.2019.

4 В. А. Ачкасов, Роль «исторической политики» в формировании российской идентичности, „Журнал социологии и социальной антропологии”, 2015, Т. 18, № 2, с. 182.

5 J.W. Müller, Introduction: the Power of Memory, the Memory of Power and Power over Memory, [in:] Memory and Power in Post-War Europe. Studies in the Presence of the Past, ed. by J.W. Müller, $2^{\text {nd }}$ ed. Cambridge: Cambridge University Press, 2004, p. 1-35.

6 О.Ю. Малинова, Актуальное прочлое: Символическая политика властвующей элиты и дилеммы российской идентичности, Москва: Политическая энциклопедия, 2015, с. 13.

7 Е.И. Филиппова, История и память в эпоху Господства идентичностей (беседа с действительным членом Французской Академии историком Пьером Нора, „Этнографическое обозрение”, № 4, 2011, с. 77.

8 Польша - Россия. Поиски новой идентичности. Сходства и различия, ред. А. Д. Ротфельд, Варшава, 2017, т. 2, с. 13-14. 
ты О. Малиновой, А. Миллера, И. Семененко․ О. Малинова включает политику памяти в структуру более широкого явления - символической политики, в то время как А. Миллер предпочитает говорить об исторической политике, рассматривая её российский вариант в сравнении с польской и украинской практикой.

Дискуссии, начавшиеся в 2008 году вокруг подготовки единого учебника истории, расширили круг исследователей, обративших внимание на проблемы исторической памяти и её использования властными элитами для конструирования новой российской идентичности, включив историков, философов, социологов ${ }^{10}$.

Необходимость логично выстроенного повествования о прошлом, формирующего представления о коллективном опыте существования очевидна, однако такая работа таит серьезные угрозы, особенно, когда отбор событий для включения в курс истории монополизирован властной группой. А. Миллер в 2009 году сформулировал возможные деформации на основании изучения польского и украинского опыта.

Во-первых, «история и память представляются некоей ареной борьбы с противниками как внутри страны, так и за рубежом» ${ }^{11}$. Во-вторых, происходит прямое ограничение свободы высказывания, вытеснение «неугодных взглядов на обочину медийного поля, изменение принципов финансирования» ${ }^{12}$. В-третьих, альтернативные взгляды воспринимаются как угроза, на которую надо реагировать через отстаивание противоположного аргумента; разрушается пространство для диалога внутри страны. В-четвертых, новую историческую политику обосновывают тезисом о том, что патриотизм и преподавание школьной истории находятся в плачевном состоянии ${ }^{13}$.

Использование актуализированного прошлого ${ }^{14}$ политическими акторами становится обычной практикой. «С помощью исторической политики борются за голоса избирателей, устраняют конкурентов» ${ }^{15}$. В то же время, одна из актуальных задач федеративного государства - включение спорных вопросов исто-

9 О.Ю. Малинова, Актуальное прошлое: Символическая политика властвующей элиты и дилеммы российской идентичности, Москва: Политическая энциклопедия, 2015, 207 с.; А. Миллер, Политика памяти в посткоммунистической Европе и ее воздействие на европейскую культуру памяти, Гефтер. 29.04.2016, http:/gefter.ru/archive/18391, 24.10.2018.; И.С. Семененко, Политика идентичности и идентичность в политике: этнонациональные ракурсы, европейский контекст, „Полис. Политические исследования”, 2016. № 4, с. 8-28.

10 Н. Е. Копосов, Память строгого режима: История и политика в России, Москва: Новое литературное обозрение, 2011, 320 с.; Е. Кочнева, Политика памяти в России как систематическая работа с прошльм, «Дискурс-Пи», Екатеринбург, 2015, №4, т. 12, с. 50-55.

11 А. Миллер, Россия: Власть и история, «Pro et Contra», 2009, май - август, с. 11.

12 Ibidem, c. 6-23.

13 Ibidem, c. 13.

14 Актуализированное прошлое - это исторические события, фигуры, которые имеют символическое значение для современных политических, идеологических или культурных практик.

15 А. Миллер, Россия: Власть и история, «Pro et Contra», 2009, май - август, с. 11. 
рии таким образом, чтобы способствовать консолидации общества, а не порождению новых противоречий и расколов.

Сплоченность народа, его «выживаемость» в изменяющихся условиях, во многом зависят от наличия общей идентичности, адаптированного прошлого опыта совместных переживаний и решения общих проблем. Интерпретация коллективного прошлого представляется сложным и не однонаправленным процессом, который аккумулирует, как имеющиеся знания, так и конструкты. Историческая память может рассматриваться ядром идентичности. По мнению В. Тишкова, «без истории нет и самой идентичности, если понимать под последней чувство сопричастности с той или иной общностью, культурой, ценностью» ${ }^{16}$. Для современной политики значение имеет не сама история, как наука о прошлом, а её интерпретация в актуальном дискурсе. «Политика работает не с прошлым (ибо это то, чего больше нет), - пишет О. Малинова, - а с социальными представлениями о прошлом. Причем она имеет дело не столько с историей - систематической реконструкцией прошлого, основанной на критическом отборе, сколько с тем, что принято называть коллективной памятью, то есть с социально разделяемым культурным знанием о прошлом, которое опирается на разные источники и отличается принципиальной неполнотой и избирательностью» ${ }^{17}$.

Работая со сложными конструктами формирования идентичности, необходимо обозначить границы исследования и определить основные термины. Поскольку политологи оперируют практически как синонимами терминами «политика памяти» и «историческая политика», то следует определить их соотношение.

А. Миллер определяет историческую политику как особую конфигурацию методов, предполагающих «использование государственных административных и финансовых ресурсов в сфере истории и политики памяти в интересах правящей элиты» ${ }^{18}$. В то же время реальная практика не позволяет ограничивать осмысление работы с историческим сознанием населения исключительно государственными акторами.

Дефиниция «политики памяти», предложенная О. Ю. Малиновой, трактующей её как «деятельность государства и других акторов, направленную на утверждение тех или иных представлений о коллективном прошлом и формирование поддерживающей их культурной инфраструктуры, образовательной

16 В.А. Тишков, Историческая культура и идентичность, „Уральский исторический вестник”, 2011, № 2 (31), c. 4-16.

17 О. Малинова, Коммеморация исторических событий как инструмент символической политики: возможности сравнительного анализа, „Полития”, 2017, №4, с. 6.

18 А.И. Миллер, Историческая политика в Восточной Европе начала ХХІ век, [в:] Историческая политика в XXI веке: Сборник статей, ред. А. И. Миллер, М. Липман, Москва: Новое литературное обозрение, 2012, с. 19. 
политики, а в некоторых случаях - и законодательного регулирования» ${ }^{19}$, представляется более точно отражающей протекающие в регионах процессы.

Для понимания механизма осуществления политики памяти стоит остановиться на мнемонических акторах (политических силах, заинтересованных в особом понимании прошлого $)^{20}$. Ключевым актором было и остается государство. Однако институт государства включает множество властных групп на разных уровнях, со своими представлениями о целях и направлениях необходимой актуализации прошлого. Поэтому целесообразно выделять в качестве самостоятельных акторов федеральные и региональные элить, обладающие административными ресурсами. Очевидно, что использование исторической памяти в политических целях характерно для различных политических сил, как организационно оформленных в партии и движения, так и не имеющих институциональной структуры. В.А. Шнирельман выделяет религиозные организации «с их собственными мемориальными комплексами, ритуалами, праздниками и историческими нарративами», общественные организации и частных акторов (частные музеи, веб-сайты и др. ${ }^{21}$. Пьер Нора включает в число акторов меньшинства, которые «вдруг ощутили потребность заявить о своем существовании, отстоять свою отличительность, “возвратив” себе свое прошлое» 22. Развитие информационных технологий и появление возможности влияния на общественное сознание через социальные сети, интернет-ресурсы выдвигает в число ключевых акторов формальных и неформальных лидеров общественного мнения. Однако любые конструкты, меняющие сущность понимания исторических событий, транслируются на общество, социум, который уже имеет определенное представление о прошлом - «коллективную память». Поскольку память представляет собой эмоциональное переживание, связана «с прямым или опосредованным личным переживанием событий прошлого» ${ }^{23}$, то сощзим (различные социальные группы) воспринимает и адаптирует только те смыслы, которые близки или созвучны его восприятию прошлого. Поэтому не стоит рассматривать социум только как объект политики памяти, одновременно он выступает и в качестве субъекта.

В монографии под редакцией М. Бернхарда и Дж. Кубика выделено 4 типа мнемонических акторов:

19 О. Малинова, Коммеморация исторических событий как инструмент символической политики: возможности сравнительного анализа, с. 9.

20 Twenty Years after Communism: The Politics of Memory and Commemoration, (eds.) Bernhard M., Kubik J., Oxford: Oxford University Press, 2014, p. 4.

21 В.А. Шнирельман, Социальная память: вопросы теории, [в:] Историческая память и российская идентичность, под. ред. В.А. Тишкова, Е.А. Пивневой, Москва: РАН, 2018, с. 25.

22 Е.И. Филиппова, История и память в эпоху Господства идентичностей (беседа с действительным членом Франиузской Академии историком Пьером Нора, „Этнографическое обозрение”, № 4, 2011, с. 81.

23 Ibidem, c. 75. 
«1) мнемонические бориы (mnетопіс warriors), представляют свое ви́дение прошлого как единственно верное и стремятся делегитимировать нарративы оппонентов, проводя границу «свой» - «чужой»;

2) мнемонические плюралисты (mnemonic pluralists) не только принимают как факт наличие иных интерпретаций, но и признают их право на существование; они готовы вести переговоры с оппонентами;

3) мнемонические уклонисты (mnemonic abnegators) по тем или иным причинам избегают активного участия в реинтерпретации коммеморируемого события;

4) обращенные в будущее (prospectivists) убеждены, что разгадали загадку истории и обладают ключом к будущему; они так же агрессивны, как и «борцы», но в отличие от них действуют на основе веры в «истинность» своего знания не прошлого, а будущего» ${ }^{24}$.

Не отказываясь от предложенной классификации, стоит отметить, что она в большей степени актуальна для общегосударственного уровня, чем для регионального, где подобные стратегии не столь очевидны, а исторически значимые дискуссионные события интерпретируются через призму региональной коллективной памяти.

Политика памяти может осуществляться на нескольких уровнях: государственном, региональном, этническом. При этом не обязательно, чтобы предлагаемые конструкты противоречили друг другу, однако, они могут и не совпадать с интерпретациями значимого прошлого, выбора героев и антигероев, значимых сюжетов истории.

Стремление центральной власти в России выработать единую картину прошлого не может полностью убрать из дискурса интерпретации, исторические мифы и коммеморации, которые значимы для регионального сообщества.

\section{Европейские и российские тренды в политике памяти в постсоветский период}

Российский опыт поиска новых основ идентичности не уникален, более того, осознание важности работы с прошлым приходит в российский научный дискурс во многом под влиянием зарубежных работ. Неслучайно, в ряде публикаций отечественных авторов можно встретить англоязычное название направления исследований - memory studies. Окончание Холодной войны, третья волна демократизации, расширение глобальных процессов оказали существенное влияние на европейский дискурс. Точкой отсчета поиска новой идентичности стал 1989 год, когда исчезают ограничения на свободу в посткоммунистических странах Центральной Европы.

24 Цит. по: О. Малинова, Коммеморация исторических событий как инструмент символической политики: возможности сравнительного анализа, с. 16. 
Первым трендом становится стремление отказаться от бывшего коммунистического опыта, «забыть» его. В этот период в Польше, Чехии и других странах ключевым вопросом становится уход от идентичности «советского человека» («homo sovieticus», как обозначили этот тип идентичности российский философ Александр Зиновьев и польский профессор Юзеф Тишнер ${ }^{25}$ ) и поиск новой парадигмы. Период эйфории от выхода из коммунистической системы приводит к тому, что большая часть социума тяготеет к солидарной оценке прошлого. Однако поиск альтернативной идентичности шел по двум направлениям: общеевропейской и национальной. Плюрализм мнемонических акторов, возможность появления расколов на почве исторической памяти, осознаются государствами. В результате, во многих странах Европы были созданы «Институты памяти», призванные формировать определенные интерпретации прошлого. Один из примеров такого института - польский Институт национальной памяти (ИНП), «образованный в 1998 году на базе Комиссии по расследованию преступлений против польского народа, название которой однозначно указывает на главные задачи данного учреждения» ${ }^{26}$.

Вторым трендом стала активная политика государства в сфере исторической памяти. Роль государства в проведении политики памяти не ограничивается созданием институтов, включает также принятие законов. Например, во Франции действуют четыре мемориальных закона, принятых после 1989 года - «закон Гайсо» (об уголовной ответственности за отрицание Холокоста), закон от 2001 г., признающий геноцид армян в Турции в 1915 г. и два постколониальных закона.

Третий тренд характерный для Европы - поиск объединяющих нарративов. Таким базовым элементом европейской политики памяти стал Холокост. «В основе такого подхода - понимание уникальности Холокоста как главной европейской трагедии XX века, осознание коллективной вины и ответственности всех народов Европы за эту трагедию» ${ }^{27}$. Ключевая роль Холокоста в политике памяти Европы и в целом Запада получила институциональное воплощение в таких структурах, как Международный альянс памяти Холокоста, Всемирный форум памяти Холокоста и т.д.

В то же время в ЕС признают, что общеевропейская идентичность пока не сложилась. «Споры о «правильной» коллективной памяти также обнажают основополагающие различия между европейскими странами, которые вновь заставили говорить о себе после окончания холодной войны. Основные тенденции следующие. Западная Европа (особенно Соединенное Королевство) и Россия по-прежнему относятся ко Второй мировой войне как к победе над нацизмом.

25 А. Зиновьев, Гомо советикус, Собрание сочинений в 10 томах, Том 5, Москва: Центрполиграф, 2000, c.477; J. Tischner, Etyka solidarności oraz Homo sovieticus, Znak, 1992, s. 218.

26 А. Миллер, Политика памяти в посткоммунистической Европе и ее воздействие на европейскую культуру памяти, „Гефтер”, 29.04.2016, http://gefter.ru/archive/18391, 24.12.2018.

27 А. Воронович, Д. Ефременко, Политика памяти по-киевски, „Россия в глобальной политике”, 30 октября 2017, https://globalaffairs.ru/number/Politika-pamyati-po-kievski-19124, 10.01.2019. 
Европейские страны Средиземноморского региона (Испания, Италия, Греция) пытаются понять и решить проблему появления в них тоталитаризма в XX веке. Центральная и Восточная Европа стараются возродить свою идентичность на основе концепций подавленного национального единства (с последующим напряжением в отношениях с соседними государствами - Словакией, Венгрией, Румынией, Македонией, Украиной и др.)» ${ }^{28}$.

Четвёртый тренд - политика «секуляризации», основанная на поисках угроз со стороны «значимого другого». После крушения коммунистических режимов в Восточной Европе, страны стали формировать нарратив титульной нации как «жертвы коммунистического режима». Ключевым элементом европейских исторических нарративов выступает Россия как источник угрозы. В европейской политике памяти данная тема имеет глубокие корни. Как показал Ивэр Нойманн, взгляд на Россию как на «варвара у ворот» доминировал в европейской мысли на протяжении последних трех веков, иногда уступая место восприятию России как «вечного подмастерья». После распада СССР базовые компоненты этого дискурса не изменились ${ }^{29}$. В апреле 2009 года Европейский парламент объявил 23 августа, день подписания пакта Молотова - Риббентропа, днем памяти жертв тоталитарных режимов.

Немецкий политолог Клаус Леггеви, анализируя проект Дома европейской истории, выдвинув идею о семи концентрических кругах политики памяти ЕС на основе ключевых календарных дат и «мест памяти» ${ }^{30}$, включил туда шесть негативных нарративов и только один позитивный - это нарратив истории успеха Европы после 1945 года.

Однако кризис 2008 года, Брекзит, миграционная ситуация привели к изменению настроений в Европе и появлению нового тренда - приоритета национальной истории над общеевропейскими нарративами.

Россия вступила в проект формирования новой идентичности примерно в то же время. Поэтому изначально часть трендов, характерных для посткоммунистических стран, нашли воплощение и в российской практике. По мнению О. Малиновой, описывающей изменения в политике памяти в России, есть 3 стратегии формирования нового постсоветского нарратива: что-то требовалось вспомнить, что-то попытаться «забыть», что-то увидеть в новом ракурсе ${ }^{31}$.

Стоит выделить несколько этапов политики памяти в России после 1989 года.

28 Э. Брикс, Политика памяти после холодной войнь в Европе, Санкт-Петербург:: СПбГУП, 2016, c. 8-9.

29 И. Нойманн, Использование «Другого»: Образы Востока в формировании европейских идентичностей, Москва.: Новое издательство, 2004, с. 336.

30 C. Leggewie, Seven circles of european memory, "Eurozine", Wien, 2010, 20 December, Mode of access: http://www.eurozine.com/articles/2010-12-20-leggewie-en.html, 10.01.2019.

31 О. Ю. Малинова, Официальньй исторический нарратив как элемент политики идентичности в России: от 1990-х к 2010-м годам, «Полис. Политические исследования», 2016, №6, c. $139-158$. 
Первый этап - начало 1990-х - отказ от тоталитаризма, реабилитация жертв режима, создание мест памяти (установка памятников, создание музеев). Этот период укладывается в общеевропейский тренд. Однако, даже тогда, общественное сознание оказалось расколотым. Для отдельных социальных групп слишком болезненным был переход к новой системе. Со стороны власти наблюдались попытки повлиять на переосмысление предыдущего опыта в русле общеевропейского осознания коллективной вины за жертвы советского периода.

Bmopoй эman. Со второй половины 1990-х годов, базовые тренды меняются. С одной стороны, предшествующая риторика не находит широкой поддержки, с другой - экономический кризис усиливает разочарование населения в демократических реформах, легитимность власти падает. Попытки сгладить раскол, выдвинув идею «примирения» различных сторон (коммунистов и демократов) не реализуется. Это особенно заметно на примере попытки переосмысления революции 1917 года и гражданской войны. Реабилитируются новые герои, которые ранее воспринимались как противники, но на сущность восприятия их обществом это мало влияет. Фактически власть не проводит последовательной и продуманной исторической политики. На этом фоне резко возрастает число мнемонических акторов, предлагающих свое видение истории.

Третий этап политики памяти связан со вступлением в должность президента В. В. Путина. Интерес к политике памяти со стороны государства проявляется не сразу. Властью осознается необходимость легитимации политического режима, а также собственно России как национального государства. Происходит отказ от предыдущих паттернов. Постепенно становится понятно, что Россия не стала «европейским государством», и не воспринимается в полной мере таковым на мировой арене. Главными нарративами становится тысячелетняя история, куда входит как дореволюционная Россия, так и СССР. А с 2005 г. начинается процесс реабилитации советского опыта. В этот период политика памяти противоречива и непоследовательна. Попытки объединить разный исторический опыт, не давая ему оценку, не позволяет в полной мере реализовывать внятную политику памяти, формировать общегосударственную идентичность, несмотря на то, что эта задача декларируется. Пересмотр общей истории в соседних государствах, приводит к «войнам памяти». Желание обосновать легитимность появления нового государства, постсоветские страны формируют значимого «Другого» (России), подчеркивая «коренное отличие». Радикальная ревизия общей истории, осуществленная новыми суверенными народами, породила в постсоветской России феномен «утраченного прошлого». В сознании русских глубоко укоренен имперский синдром - синдром «старшего брата», и потому стремительное превращение «братских народов СССР» в претендующих на значимость «Других» вызвали шок и обиду на неблагодарных «младших братьев» ${ }^{32}$.

32 В.А. Ачкасов, Роль «исторической политики» в формировании российской идентичности, „Журнал социологии и социальной антропологии”, 2015, т. 18, № 2, с. 183. 
Пересмотр основных паттернов дает старт четвертому этапу. Здесь характерна «секуляризация» истории, формируется ощущение «осажденной крепости», что проявляется в актуализации различных исторических событий, связанных с защитой Отечества. Главным нарративом становится Великая Отечественная война. Любые попытки других мнемонических акторов дать оценку различных событий Великой Отечественной войны или пересмотреть отдельные результаты Второй мировой войны, воспринимаются как нападение на ценности, в логике «войн памяти». Экономические кризисы, санкционная война, коллективная память, повлияли на возрастание поддержки положительных героев и фреймов, связанных с советским прошлым. Попытки власти и церкви заменить советских героев (прежде всего Сталина) Александром Невским или Николаем II оказались не очень успешными. Они были включены коллективным сознанием в число героев, но не заменили уже имеющихся.

Работу с памятью в России сложно назвать эффективной, поскольку наличие различных мнемонических акторов, в значительной степени мнемонических борцов (по классификации М. Бернхарда и Дж. Кубика) не позволяет консолидировать общество на основе общих ценностей. А события 2014 г., когда Крым был присоединен к России, привели к ещё большему расколу в социуме. В настоящее время политические элиты осознали необходимость проведения политики памяти для сохранения стабильности, поддержания легитимности и развития общегражданской идентичности. Однако, не имея целостной стратегии, невозможно и достижение конкретного результата. Этот процесс осложняется недостаточным авторитетом у населения историков, общественных деятелей, которые пытаются предлагать различные конструкты или коммеморальные практики.

\section{Региональные метаморфозы политики памяти: кейс Воронежской области}

Для Воронежской области, преимущественно этнически русского региона, проблема исторической памяти не столь очевидна, как, например, для национальных республик в составе России. Однако региональные интерпретации «трудных вопросов истории» значительны.

Эйфория освобождения от коммунизма начала 1990-х годов в регионе быстро прошла. Воронежская область попала в «красный пояс». Э. Внук-Липиньский полагает, что «участие в свободных выборах является приблизительным показателем выкристаллизовавшихся гражданских идентичностей» ${ }^{33}$. Выборы того периода обнаружили, что значительная часть жителей осталась в рамках парадигмы советского человека. В 1990-годы в Воронежской области серьезной поддержкой пользовалась коммунистическая партия. Не углубляясь в анализ причин, можно только отметить, что среди значимого прошлого для жителей региона советское прошлое не представлялось исключительно в негативном свете.

33 Э. Внук-Липиньски, Польша после 1989 года: поиск новой идентичности, [в:] Польша - Россия. Поиски новой идентичности. Сходства и различия, ред. А. Д. Ротфельд, Варшава, 2017, т. 2, с. 54. 
В этот период руководителем региона был И. М. Шабанов, представитель старой номенклатуры, пришедший на смену «демократу» А. Ковалёву. Поставленный в 1990-е годы вопрос об интерпретации советского прошлого, оказался крайне сложным, вызвавшим глубокий раскол в обществе.

В разные исторические периоды взгляды на события менялись. В период президентства Б. Ельцина предлагалось сосредоточить внимание на цене достижений советского периода, усилить «чувство вины» и «травмы», чтобы сформировать новую демократическую Россию. Это не укоренилось в сознании большинства людей, однако было востребовано отдельными группами. Акцентирование «чувства вины» претерпело ритуализацию в форме акций публичного чтения списков репрессированных в День памяти жертв политических репрессий в гайд-парке Воронежа. Это ежегодное мероприятие, проводимое общественниками в разных городах России. Наряду с неофициальными, в области происходят в этот день и мероприятия с участием представителей власти - на «Аллее Скорби», расположенной в лесном массиве в поселке «Дубовка»- митинги и перезахоронение останков репрессированных. Раскопки в мемориальной зоне продолжаются в соответствии с проектом «Память», разработанным городской комиссией по восстановлению прав жертв политических репрессий и комиссией правительства Воронежской области ${ }^{34}$. Показательно, что возникнув как стихийное «место памяти», мемориал стал официально признанным, включенным в реестр памятников.

Сложились два лагеря - тех, кто считал СССР тоталитарным государством и по этой причине акцентировал внимание исключительно на негативных сторонах советского прошлого, и тех, кто испытывал ностальгию по СССР, обращал внимание на достижения того периода. Проблема интерпретации советского прошлого была связана с легитимностью власти, с преемственностью государственности.

Позиция региональной власти в области исторической политики отличалась непоследовательностью. Во-первых, изначально, как на федеральном, так и на региональном уровнях не было понимания не только необходимости проведения политики памяти, но и того направления, в котором следовало выстраивать эту работу. Во-вторых, это было обусловлено ожиданием указаний Центра.

Распад СССР всколыхнул интерес к закрытым ранее страницам истории, в результате эту нишу стали активно заполнять псевдонаучные исследования, формирующие новые мифы. Ограниченная доступность серьезных научных работ, посвященных советской истории, замещение их сомнительными публикациями, вызвали среди населения разочарование, в результате которого многие стали переосмысливать свои взгляды.

34 В Воронеже прошли мероприятия, посвященные Дню памяти жертв политических репрессий, Официальный сайт городской администрации, http://www.voronezh-city.ru/communications/ msgs/detail/27374, 8.01.2019. 
Противоречивость позиции региональной власти по отношению к советскому прошлому повлияла на инерционный характер любых действий, затрагивающих это направление. С одной стороны, это была вынужденная реакция транслировать фреймы, предложенные на федеральном уровне, с другой - раскол в обществе по отношению к прошлому не позволял занять им определенную позицию, из-за боязни утратить легитимность. В результате можно наблюдать символические действия в уступках обеим сторонам. Так, в 2014 г. году в Бутурлиновке был восстановлен памятник Александру II на площади Воли, исчезнувший в советское время. А уже в 2018 г. в Санатории им. Дзержинского восстанавливают памятник Ф. Дзержинскому, который ранее снесли, но сохранили в подвале санатория.

Попытки управления памятью на региональном уровне сложно назвать успешными. Если в ряде европейских стран отказ от советского прошлого был построен на возложении значительной вины на СССР, с последующей интерпретацией переноса вины на Россию (публичные заявления о претензиях к России), то для России это оказалось слишком проблематичным. Использование национальной карты - перенос вины на представителей не русских этнических групп, находившихся у власти, оказался также невозможен из-за полиэтнического характера государства.

В 2000-е годы меняются федеральные тренды. В послании Президента Федеральному Собранию РФ в 2005 г. Путин назвал распад СССР «величайшей геополитической катастрофой» ${ }^{35}$, тем самым реабилитировал советское прошлое и особенно достижения науки, литературы, освоение космоса. Эта идея становится созвучна значительному числу россиян. Рост интереса к положительной интерпретации советского прошлого обусловлен не только политикой центра. Запрос на справедливость, которую не смогла обеспечить действующая власть, отразился в реинкарнации идеологем и героев советского периода.

Для Воронежской области данное событие имеет ещё и региональный контекст. Приграничный характер территории повлиял на выстраивание коммуникаций с соседней Украиной, наличие друзей и родственников, которые с распадом государства оказались по разные стороны границы, при том, что отношения двух стран ухудшились. «Дружба народов», которая официально провозглашалась в СССР, вызывает ностальгические чувства, при этом комплекс «обиды на младшего брата» не проявляется в региональном сознании.

Так, по данным опроса социологического агентства «Квалитас», 23\% воронежцев «если бы была возможность изменить / исправить одно событие в истории страны», сохранили бы Советский Сою $3^{36}$. Для сравнения - 13,5\% в качестве такого события указали революции 1905 и 1917 гг, 0,8\% - сталинские репрессии.

35 Послание Президента Российской Федерации В.В. Путина Федеральному Собранию Российской Федерации, Официальный сайт Администрации Президента, http://www.kremlin.ru/events/ president/transcripts/22931, 2005 г., 8.01.2019.

36 Квалитас, http://www.qualitas.ru/ru/publications/bulletin/2016/August, Ежемесячный бюллетень социологических сообщений по г. Воронежу № 2016-08 (224), 8.01.2019. 
Инерционный характер работы с исторической памятью властными структурами способствовал развитию плюрализма акторов политики памяти. Конструирование идентичности, формирование новых мифов стало делом разных политических сил. Экономические трудности становятся объектом манипуляций со стороны лево-радикальных групп, пытающихся реанимировать память о И. Сталине как гениальном руководителе, эффективном менеджере, что отражается на настроениях жителей региона.

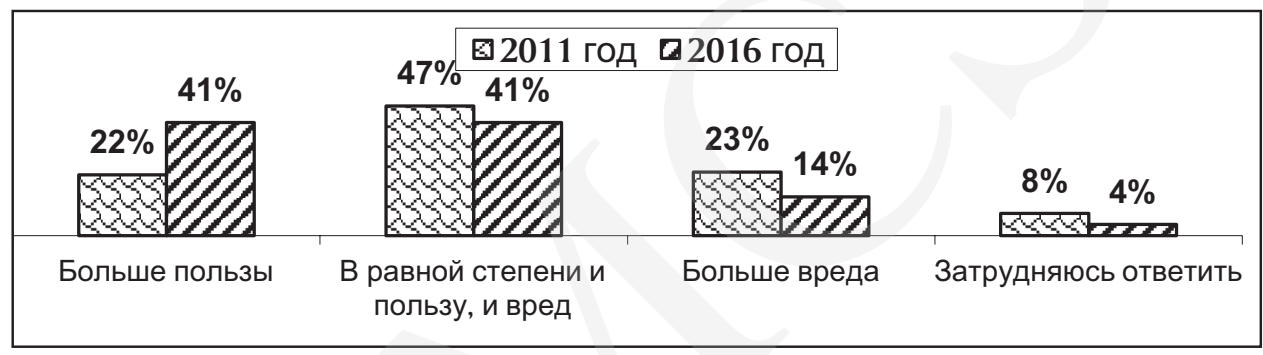

Таблица 1. Как Вы считаете, И. В. Сталин принес нашей стране в целом больше пользы или больше вреда?

Источник: Квалитас, Ежемесячный бюллетень социологических сообщений по г. Воронежу № 2016-09 (225) http://www.qualitas.ru/ru/publications/bulletin/2016/September, 8.01.2019.

Стремление пересмотреть советскую историю в соседних государствах (создание польского Института национальной памяти (ИНП) в 1998 году, Украинского института национальной памяти (УИНП) в 2006 году, «Музея геноцида» в Вильнюсе, посвященного не Холокосту, а «советской оккупации» и др.) вызывает защитную реакцию федеральной власти, обращение к образу героического прошлого. Особую актуальность приобретает нарратив Великой Отечественной войны.

Великая Отечественная война для Воронежской области также стала значимым фреймом для формирования региональной идентичности. 212 дней линия фронта проходила по городу Воронеж, но фашистам так и не удалось взять город полностью. В регионе шли кровавые бои. Кроме немецких войск, здесь находились также итальянские и венгерские части. Долгое время региональной обидой было отсутствие звания Город-герой у Воронежа, что описывалось в литературных произведениях, исторических исследованиях.

По словам В. А. Шнирельмана, для понимания самого феномена исторической памяти необходимо рассматривать роль субъектов и институтов памяти, наделенных властью, а также воздействие своего рода исторических катаклизмов, особенно коллективных травм и т. н. «исторических несправедливостей» ${ }^{37}$. В качестве такой «исторической несправедливости» региональное сообщество

37 Историческая память и российская идентичность, под. ред. В. А. Тишкова, Е.А. Пивневой, Москва: РАН, 2018. с. 7. 
воспринимало отсутствие у Воронежа звания «Города-героя». Дискуссия относительно роли Воронежского сражения не прекратилась полностью даже после присвоения звания «Город воинской славы» в 2008 году. Особенно она актуализировалась как реакция на федеральный тренд попыток пересмотра итогов, хода сражений, целесообразности тех или иных решений.

Героизация этого периода в значительной степени связана с локальным контекстом: борьба за присвоение звания «Город воинской славы», установка у Центрального железнодорожного вокзала памятника генералу И. Д. Черняховскому, вывезенному из Литвы после его демонтажа в 1993 году, ежегодная историческая реконструкция «Боев за Воронеж», посвященная Дню освобождения Воронежа.

Региональная интерпретация выглядит неоднозначной - от попыток нивелирования событий до абсолютизации роли боёв за Воронеж для решающего наступления в годы войны. При этом не ограничиваются научными дискуссиями, а имеют выход на практические действия. В начале 1990-х годов в регионе были облагорожены военные кладбища бывших противников: венгерские, немецкое, итальянское захоронение. В 1993 г. в Россоши был открыт построенный итальянцами детский садик, на том месте, где в войну располагался их штаб. В 2003 г. открыли памятник погибшим «оккупантам»- альпийская шляпа с пером. Представители местной администрации, региональные власти в тот момент рассматривали памятник, как приемлемый, поскольку наблюдался тренд на примирение. Ветераны, которые отнеслись к данному действию негативно, были в меньшинстве. Однако изменение общего контекста отношения к роли СССР во Второй мировой войне, отразилось на настроениях жителей региона. Ситуация обострилась перед выборами губернатора Воронежской области 2018 г. Наличие памятника «оккупантам» рассматривается жителями как негативная коммеморация, попытка узаконить пересмотр итогов войны, что вызывает волну протестов и широкую медийную поддержку. Неопределенность позиции региональной власти по отношению к памятнику усложняет картину.

Фактически, официальные структуры региона слабо и медленно реагируют на вызовы, отдавая приоритет конструирования региональных нарративов другим акторам. Если В. Ачкасов полагает, что историческая политика России реактивная ${ }^{38}$, то региональная историческая политика - слабо реактивная. В региональной политике памяти наблюдается плюрализм мнемонических акторов, противоречивый характер восприятия основных нарративов.

Относительный консенсус сложился по нескольким значимым для региона нарративам: это значение Петра I и «человека из Костёнок». При поиске значимых фигур в прошлом личность Петра I наиболее универсальна. Она устраивает региональные власти как сильная фигура монарха, осуществившего реформы и модернизацию; консерваторов - как личность из дореволюционного прошло-

38 В. А. Ачкасов, Роль «исторической политики» в формировании российской идентичности, C. $181-192$. 
го; либералов - как европейски ориентированного государственного деятеля. Для населения Петр I важен как царь, сделавший регион и его столицу значимым местом на карте страны, где фактически во время строительства флота находился двор, принимались государственные решения. С именем Петра I связаны мероприятия по увековечиванию памяти, инициированные как сверху (например, постройка музея - копии корабля «Гото Предестинация» в 2014 г.), так и локальными сообществами (установка 3 октября 1997 года в период празднования 345-летия со дня основания города Острогожска памятного камня на месте встречи Петра I с гетманом Мазепой).

Социологические опросы и участие в проектах, связанных с историческими личностями, фиксируют оценку значимости Петра I в исторической памяти воронежцев. Это продемонстрировали результаты проекта «Великие имена России». Этот проект предполагает присвоение крупным аэропортам имен выдающихся деятелей, связанных с регионом по итогам голосования жителей. Воронеж по числу проголосовавших за Петра I обошел Санкт-Петербург (всего 85171 человек, или $59 \%$ сделали выбор в пользу имени Петра I для воронежского аэропорта) ${ }^{39}$.

Отсутствие четкой стратегии выстраивания региональной идентичности в контексте общегражданской приводит к сложным реакциям региональной власти и влияет на восприятие других исторических периодов. Так, политика удревнения городов укладывается в концепции тысячелетней истории России. Празднование 1000-летия Казани, высказывание главного археолога Москвы Леонида Кондрашева о том, что реальный возраст Москвы больше, и что историки могут его пересмотреть ${ }^{40}$. Установка памятника Ивану Грозному в Орле, удревнение Белгорода укладываются в логику начавшегося тренда. Региональные элиты с опаской отнеслись к возможности реализации каких-либо попыток удревнения Воронежа, предполагая, что это может сказаться на финансовых поступлениях. Археологические раскопки в центре Воронежа, на месте бывшей крепости, не стали объектом музеефикации. Лакуной воспользовались другие акторы, которые в рамках мифотворчества возводят истоки города то к ариям, то к иным не менее древним предкам. Наиболее удачным и научно обоснованным (хотя бы частично) стало формирование имиджа региона как места обитания самого первого европейца - «человека из Костёнок». Археологические данные и удовлетворение амбиций различных групп помогли прийти к консенсусу относительно этого фрейма.

Федеральный уровень политики памяти позволяет нам проследить этапы изменения базовых нарративов. В то же время региональная политика не имеет столь явно выраженной динамики за небольшим исключением. В период губернатора А.В. Гордеева (2009-2017 гг.) наблюдается попытка синхронизации федераль-

39 Сайт Великие имена России. Результаты, https://великиеимена.pф, 8.01.2019.

40 Историки задумались о пересмотре возраста Москвы, Сайт РИА Новости, https://ria.ru/ society/20170815/1500424384.html, 26.12.2018. 
ных трендов с региональными практиками. Но каких-либо активных действий в этом направлении не просматривается. Более того, в этот же период стратегия регионального правительства меняется - от попытки транслировать федеральные нарративы происходит смещение акцентов к региональным фреймам, поддерживаются те актуализированные события, которые присутствуют в локальном дискурсе. Происходит работа с возрождением региональных мест памяти.

В целом по стране наблюдается рост патерналистских настроений, что прослеживается также и в Воронежской области. Однако региональная власть не дает адекватного ответа на этот запрос, предпочитая оставаться ведомой и слабо реагировать на вызовы. Региональное правительство, как мнемонического актора согласно классификации М. Бернхарда и Дж. Кубика, можно отнести к типу мнемонических уклонистов, поскольку оно предпочитает избегать активного участия в интерпретациях различных исторических событий. В то же время, как в рамках элиты, так и вне её проявляют активность другие мнемонические акторы, предлагающие свои значимые фреймы для влияния на коллективную память. Социальные сети формируют коллективного субъекта, когда запущенная информация одним из лидеров общественного мнения, многократно повторенная, перестает ассоциироваться с конкретным лицом, а переходит к группе. Использование таких механизмов прослеживается по спорным вопросам истории. Например, «война», развернувшаяся вокруг присвоения имени Петра I аэропорту.

В значительной мере на региональном уровне фиксируются тенденции, аналогичные федеральным: «секьюризация» политики памяти, рост симпатий к советскому опыту. В то же время, есть и отличительные локальные особенности. Тогда как большинство исследователей обращает внимание на снижение роли профессиональных историков в российском дискурсе, падение их авторитета, в региональном пространстве наблюдается возрастание интереса к историческим исследованиям. Региональные власти поддерживают просветительские проекты в области исторического знания через систему грантов - открытые лекции в рамках организации «Наша история», других проектов («Палеолит - это современно», «Окно в Хазарию»), не участвуя в определении их контента. При этом их внимание акцентировано на мероприятиях, связанных с коммеморацией Великой Отечественной войны, что отвечает основному направлению федеральной политике.

\section{Выводы}

Выстраивание политики памяти на региональном уровне отражает «матрёшечный» принцип, когда региональный кейс не противоречит федеральному, стремится транслировать основные тренды на региональное сообщество, но их воплощение на практике отличается от представленного образца.

Значимость исторической памяти для легитимации власти, как на уровне России, так и на уровне региона осознается основным региональным актором политики памяти - региональной элитой, но в силу разных причин, она не имеет 
комплексного видения стратегии по её осуществлению и своего места в управлении этим процессом. В результате действия власти в этом направлении представляются не только реактивными, но и происходят с запаздыванием даже по отношению к федеральным сигналам.

Серьезную конкуренцию составляют другие интеллектуальные проекты политики памяти, использующие имеющиеся у населения мифы и психотравмы прошлого, образы совместных побед и обид. В демократическом обществе всегда существует плюрализм проектов и мнемонических акторов, однако для консолидации общества необходимо сближение этих проектов, а не фрагментация и конфликтность, что по ряду вопросов фиксируется в Воронежской области.

Отсутствие комплексного взгляда на исторические нарративы приводит к усилению стихийного компонента в толковании прошлого. Желание отстроится от «лихих 1990-х» без предложенных региональной элитой положительных образцов исторического прошлого способствует росту популярности «советского пути». Это обусловлено объективными экономическими и внешнеполитическими причинами. Запрос на справедливость и «дружбу народов» трансформируется в ностальгию по советскому прошлому.

Раскол в сообществе между сторонниками разной интерпретации прошлого может усиливать ксенофобию. В то же время, прямое вмешательство государства в эту сферу, определение «правильного прошлого» будет препятствовать появлению новых исследований, открывающих ранее неизученные документы. Остается проблема разрыва между реальными историческими знаниями и мифологемами о событиях, что может быть использовано для манипуляций общественным сознанием. Противоречивость исторических нарративов, отсутствие продуманной региональной политики в этом направлении усиливает риски серьезных конфликтов и расколов в социуме.

Сохранение исторической памяти осуществимо только в процессе осмысления обществом своих побед и поражений в прошлом. Наличие региональных диссонансов в оценках трудных событий истории должно строиться исключительно на подтвержденных фактах, давать возможности новым исследованиям.

Ю. Пивоваров в своем эссе полагает, что патримониализм, рост недовольства «большей части населения, обездоленной и обескровленной» может привести к выходу на первый план националистической идеологии» ${ }^{41}$. Однако опрос общественного мнения показывает, что жители регионального сообщества скорее ориентированы на примирение разных исторических проектов, поиск компромисса по трудным вопросам истории. Это оставляет окно возможностей формирования общегражданской идентичности, где региональная идентичность будет не противоречить ей, а органично её дополнять.

${ }^{41}$ Ю. Пивоваров, Об идентичности и легитимности в современной России, [в:] Польша - Россия. Поиски новой идентичности. Сходства и различия, ред. А. Д. Ротфельд, Варшава, 2017, т. 2, c. 48. 


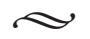

Аннотация: Целью статьи является анализ регионального уровня политики памяти. Хотя рассматривается кейс Воронежской области, ситуация в других регионах Центрального федерального округа, не имеющих ярко выраженной национальной идентичности, похожа. Отмечается, что в федеративном государстве прошлое имеет различные уровни восприятия. На уровне регионов, интерпретация и актуализация событий может не совпадать с интерпретациями общегосударственного уровня. В этой связи разводятся два понятия «историческая политика», где предполагается сознательное выстраивание элитой определенных символических конструктов, и «политика памяти», которая рассматривается как процесс, где субъектами выступают не только органы власти, но и другие акторы - политические лидеры, исследователи, общественные активисты. В эссе рассматривается влияние федеральных трендов на региональную интерпретацию значимых исторических сюжетов.

Осознание элитами значимости политики памяти для укрепления собственной легитимности, не повлияло на слабую проработанность трудных вопросов истории и отсутствие консенсуса в их интерпретации внутри самих элитных групп, что не позволяет осуществлять продуманную политику памяти. Несмотря на наличие нескольких исторических нарративов, по которым наблюдается консенсус большинства акторов, противоречивость транслируемых ценностей, усиливает стихийные процессы в коллективном «вспоминании» исторического прошлого, что приводит к дихотомии в исторической памяти и усилению фрагментации общегражданской идентичности.

В статье прослеживаются изменения в коллективной исторической памяти жителей региона, обозначены возможные негативные проявления. Делается вывод о необходимости проведения продуманной политики памяти, которая не должна подменяться навязыванием отдельных интерпретаций сверху.

Ключевые слова: политика памяти, регион, историческая политика, коммеморации, Воронежская область, мнемонические акторы

\section{Polityka pamięci: interpretacja regionalna}

Streszczenie: Celem artykułu jest analiza polityki pamięci na poziomie regionalnym. Chociaż rozpatrywany jest przypadek obwodu woroneskiego, sytuacja w innych regionach Centralnego Okręgu Federalnego, które nie mają wyraźnej tożsamości narodowej, jest podobna. Należy zauważyć, że w państwie federacyjnym przeszłość ma różne poziomy postrzegania. Na poziomie regionalnym interpretacja i aktualizacja wydarzeń mogą nie pokrywać się z interpretacjami na poziomie krajowym. W związku z tym rozchodzą się dwie koncepcje: „polityka historyczna”, w której elita ma świadomie budować pewne konstrukcje symboliczne, oraz „polityka pamięci”, która jest uważana za proces, w którym są nie tylko władze, ale także inni aktorzy - przywódcy polityczni, badacze, osoby publiczne, działacze. Esej bada wpływ trendów federalnych na regionalną interpretację znaczących fabuł historycznych.

Świadomość elit co do znaczenia polityki pamięci dla wzmocnienia własnej legitymizacji nie wpłynęła na słabe opracowanie trudnych kwestii historycznych i brak konsensusu w ich interpretacji w obrębie sa- 
mych grup elitarnych, co nie pozwala na dobrze przemyślaną politykę pamięci. Pomimo obecności kilku narracji historycznych, co do których większość aktorów jest zgodna, niespójność nadawanych wartości wzmacnia spontaniczne procesy w zbiorowym „przypominaniu” historycznej przeszłości, co prowadzi do dychotomii pamięci historycznej i zwiększonego rozdrobnienia wspólnej tożsamości obywatelskiej. Artykuł śledzi zmiany w zbiorowej pamięci historycznej mieszkańców regionu, identyfikuje możliwe negatywne przejawy. Nasuwa się wniosek o potrzebie przemyślanej polityki pamięci, której nie należy zastępować narzucaniem indywidualnych interpretacji z góry.

Słowa kluczowe: polityka pamięci, region, polityka historyczna, upamiętnienia, obwód woroneski, mnemoniczni aktorzy

\section{The Memory Politics: Regional Interpretation}

Abstract: The aim of the paper is to analyze the regional level of the memory politics. Although the case of the Voronezh region is considered, the situation in other regions that does not have a pronounced national identity is similar. It is noted that in the Federal state the past has different levels of perception. The interpretation of events at the regional level may not coincide with that at the national level. In this regard, there are two concepts of "historical policy", where the elite is supposed to consciously build certain symbolic constructs, and "the memory politics" which is considered as a process where the actors are not only the authorities, but also others - political leaders, researchers, social activists. The essay examines the influence of Federal trends on the regional interpretation of significant historical subjects.

The elites' awareness of the importance of memory policy for strengthening their own legitimacy did not affect the weak elaboration of difficult historical issues and the lack of consensus in their interpretation within the elite groups, which does not allow for a well-thought-out memory policy. Despite the presence of several historical narratives, on which there is a consensus of the majority of actors, the inconsistency of the broadcast values, enhances the spontaneous processes in the collective "remembering" of the historical past, which increased the fragmentation of civil identity. The paper traces the changes in the collective historical memory of the inhabitants of the region, identifies negative manifestations.

Keywords: memory politics, region, historical policy, commemorative, Voronezh region, mnemonic actors

\section{Источники и литература}

\section{Монографии}

Briks E., Politika pamyati posle kholodnoy voyny v Evrope, Sankt-Peterburg: SPbGUP, 2016, s. 40.

Istoricheskaya pamyat'i rossiyskaya identichnost', pod. red. V.A. Tishkova, E.A. Pivnevoy, Moskva: RAN, 2018. s. 508.

Koposov N. E., Pamyat' strogogo rezhima: Istoriya i politika v Rossii, Moskva: Novoye literaturnoye obozreniye, 2011, s. 320

Malinova 0. Yu., Aktual'noye proshloye: Simvolicheskaya politika vlastvuyushchey elity i dilemmy rossiyskoy identichnosti, Moskva: Politicheskaya entsiklopediya, 2015, s. 207. 
Müller J.W. Introduction: the Power of Memory, the Memory of Power and Power over Memory, Memory and Power in Post-War Europe. Studies in the Presence of the Past, ed. by J.W. Müller. $2^{\text {nd }}$ ed. Cambridge: Cambridge University Press, 2004. P. 1-35.

Natsional'naya ideya Rossii, v 6 t. Moskva: Nauchnyy ekspert, 2012.

Noymann I., Ispol'zovaniye «Drugogo»: Obrazy Vostoka v formirovanii evropeyskikh identichnostey, Moskva: Novoye izdatel'stvo, 2004, s. 336.

Pol'sha - Rossiya. Poiski novoy identichnosti. Skhodstva i razlichiya, red. A. D. Rotfel'd, Varshava, 2017, t. 2, s. 412.

Tischner J., Etyka solidarności oraz Homo Sovieticus, Kraków: Znak, 1992, s. 218.

Twenty Years after Communism: The Politics of Memory and Commemoration, (eds.) Bernhard M., Kubik J., Oxford: Oxford University Press 2014, p. 384.

Zinov'yev A., Gomo sovetikus, Sobraniye sochineniy v 10 tomakh, t. 5, Moskva: Tsentrpoligraf, 2000, s. 477.

\section{Статьи}

Achkasov V.A., Rol' «istoricheskoy politiki» v formirovanii rossiyskoy identichnosti, „Zhurnal sotsiologii i sotsial'noy antropologii", 2015, t. 18, № 2, s. 181-192.

Filippova E. I., Istoriya i pamyat'v epokhu Gospodstva identichnostey (beseda s deystvitel'nym chlenom Frantsuzskoy Akademii istorikom P'yerom Nora, „Etnograficheskoye obozreniye”, № 4, 2011, s. 7584.

Khal'bvaks M., Kollektivnaya i istoricheskaya pamyat', „Neprikosnovennyy zapas”, 2005, № 2-3 (40-41), http: magazines.russ.ru/nz/2005/2/ha2.html, 10.01.2019.

Kochneva E., Politika pamyati v Rossii kak sistematicheskaya rabota s proshlym, „Diskurs-Pi”, Ekaterinburg, 2015, №4, t. 12, s. $50-55$.

Leggewie C., Seven circles of european memory, «Eurozine», Wien, 2010, 20 December, http://www.eurozine.com/articles/2010-12-20-leggewie-en.html, 10.01.2019.

Malinova 0. Yu., Ofitsial'nyy istoricheskiy narrativ kak element politiki identichnosti v Rossii: ot 1990-kh k 2010-m godam, „Polis. Politicheskiye issledovaniya”, 2016, №6, s. 139-158.

Malinova 0., Kommemoratsiya istoricheskikh sobytiy kak instrument simvolicheskoy politiki: vozmozhnosti sravnitel'nogo analiza, „Politiya”, 2017, №4, s. 9.

Miller A. I., Istoricheskaya politika v Vostochnoy Evrope nachala XXI vek, [v:] Istoricheskaya politika v XXI veke: Sbornik statey, red. A. I. Miller, M. Lipman, Moskva: Novoye literaturnoye obozreniye, 2012, s.19.

Miller A., Labirinty istoricheskoy politiki, „Rossiya v global'noy politike”, t. 9, №3, 2011. s. 49.

Miller A., Politika pamyati v postkommunisticheskoy Evrope i eye vozdeystviye na evropeyskuyu kul'turu pamyati, Gefter, 29.04.2016, http://gefter.ru/archive/18391, 24.10.2018.

Semenenko I. S., Politika identichnosti i identichnost' v politike: etnonatsional'nyye rakursy, evropeyskiy kontekst, „Polis. Politicheskiye issledovaniya", 2016, № 4, s. 8-28. DOl: 10.17976/jpps/2016.04.03.

Tishkov V. A., Istoricheskaya kul'tura i identichnost', „Ural'skiy istoricheskiy vestnik”, 2011, № 2(31), s.4-16.

Voronovich A., Efremenko D., Politika pamyati po-kiyevski, „Rossiya v global'noy politike”, 30 oktyabrya 2017, https://globalaffairs.ru/number/Politika-pamyati-po-kievski-19124, 10.01.2019. 
Pobrane z czasopisma Wschód Europy http://journals.umcs.pl/we

Data: 26/04/2023 13:30:24

\section{Интернет - источники}

Kvalitas, http://www.qualitas.ru/ru/publications/bulletin/2016/August, Ezhemesyachnyy byulleten' sotsiologicheskikh soobshcheniy po g. Voronezhu № 2016-08 (224), 8.01.2019.

Poslaniye Prezidenta Rossiyskoy Federatsii V.V. Putina Federal'nomu Sobraniyu Rossiyskoy Federatsii, Ofitsial'nyy sayt Administratsii Prezidenta, http://www.kremlin.ru/events/president/transcripts/22931, 2005 g., 8.01.2019.

Sayt RIA Novosti. https://ria.ru/society/20170815/1500424384.html, Istoriki zadumalis' o peresmotre vozrasta Moskvy, 26.12.2018.

Sayt Velikiye imena Rossii. Rezul'taty, https://velikiyeimena.rf, 8.01.2019.

$\checkmark$ Voronezhe proshli meropriyatiya, posvyashchennyye Dnyu pamyati zhertv politicheskikh repressiy, Ofitsial'nyy sayt gorodskoy administratsii, http://www.voronezh-city.ru/communications/msgs/deta$\mathrm{i} / 27374,8.01 .2019$. 